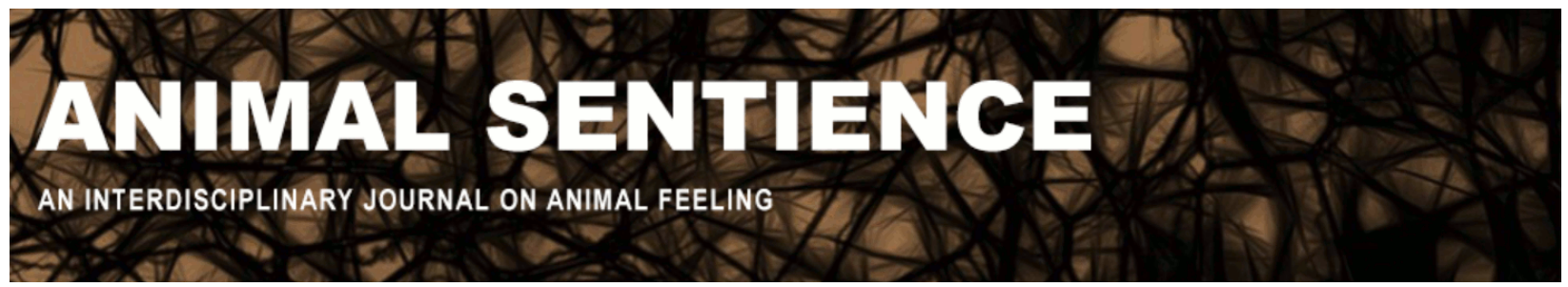

Benz-Schwarzburg, Judith (2016) From thinking selves to social selves. Animal Sentience 10(10)

DOI: $10.51291 / 2377-7478.1155$

Date of submission: 2016-08-26

Date of acceptance: 2016-08-30

(c)

This article has appeared in the journal Animal

Sentience, a peer-reviewed journal on animal

cognition and feeling. It has been made open access,

free for all, by WellBeing International and deposited

in the WBI Studies Repository. For more information,

please contact

wbisr-info@wellbeingintl.org.

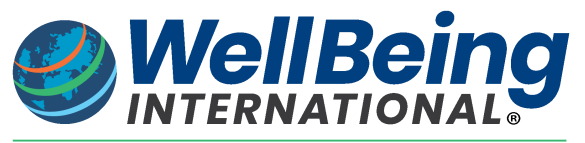

SOLUTIONS FOR PEOPLE, ANIMALS AND ENVIRONMENT 


\title{
From thinking selves to social selves
}

Commentary on Rowlands on Animal Personhood

\section{Judith Benz-Schwarzburg \\ Unit of Ethics and Human-Animal Studies, Messerli Research Institute, Vienna}

\begin{abstract}
I argue that Rowlands's concept of pre-reflective self-awareness offers a way to understand animals as Social Selves. It does so because it departs from the orthodox conception of self-awareness, which is both egocentric and logocentric. Instead, its focus is on the relation between consciousness and a person's lived body, her actions and goals. Characterizing persons as pre-reflectively self-aware beings in Rowlands's sense offers a much more useful conceptual tool to interpret social behaviour in animals.
\end{abstract}

Keywords: self-awareness, animal social behaviour, personhood, body, goals

\begin{abstract}
Judith Benz-Schwarzburg is Senior Researcher at the Unit for Ethics and Human-Animal Studies of the University of Veterinary Medicine, Vienna, the University of Vienna and the Medical University of Vienna. Her work focuses on sociocognitive abilities in animals and their ethical relevance (for culture, language, theory of mind, and morality in animals). https://www.vetmeduni.ac.at/en/messerli/science/ethik/st aff/judith-benz-schwarzburg/
\end{abstract}

Rowlands (2016) offers a notion of personhood that is detached from meta-cognitive capacities and takes its strength from the idea that pre-reflective self-awareness already guarantees the unity of the mental life of an individual. He argues that our perception of the world implies that we are implicitly aware of our own goals (I will only perceive a chair as a sit-able device if I am aware of my goal to sit down) and that we are by the same token implicitly aware of our body (the chair seems right because I am aware of my size, which fits the chair):

\footnotetext{
"I am pre-reflectively aware of my goal in virtue of the fact that certain features of the world rather than others are the objects of my conscious act of seeing. Seeing the world in this way also involves pre-reflective awareness of my body. [...] To be aware of the affordances of any object - what that object offers, whether for good or for ill - is, at the same time, to be aware of my body." (Rowlands, 2016, p. 9)
}

In this way, pre-reflective self-awareness is "built into acts of conscious experience." It is part of these experiences, which are "typically [not] about the self but about something else" (Rowlands, 2016, p. 15).

Though Rowlands's examples focus on the perception of objects (a chair, a book...), we could also include our perception and social interaction with other beings. This seems possible, as pre-reflective self-awareness is something that is connected with (and maybe enables?) action: "whenever I am aware of certain [...] possibilities for action, [...] I am simultaneously pre-reflectively aware of my body. This is so because the body is the vehicle of my action." Rowlands's (2016) focus is on the "lived body" (p. 10) and, so, we could argue, the lived body (as well as the lived mind) of an animal with socio-cognitive abilities is a body 
that facilitates and strives not just for action, but for social interaction. In social animals prereflective awareness of their own bodies and goals takes place in social interaction, but it can also take place in other forms of action: Asocial animals can still be self-aware in Rowlands's sense, but his concept also offers a way to link self-awareness and social engagement in the case of social animals.

Thus, unlike its reflective counterpart, pre-reflective self-awareness is not a separate act (Rowlands, 2016, p. 15) - and it isn't so in two respects. First, it is built into conscious experience, and thus guarantees the unity of mental states without resulting in a kind of regress (p. 15). But it is also not separate in a more profound way. I will show how this is the case by linking Rowlands's theoretical assumptions on the content of self-awareness with a claim put forward by Thomas White (1997).

White, one of the philosophers who argue in favour of understanding cetaceans as persons, lists the most important person-conferring features from the philosophical literature (referring, e.g., to Daniel Dennett's Brainstorms and Joseph Fletcher's Humanhood essays). These features include (1) being alive, (2) being aware, (3) feeling positive and negative sensations, (4) having emotions, (5) having a sense of self, (6) controlling one's own behaviour, (7) recognizing other persons and treating them appropriately, and (8) having a variety of sophisticated cognitive abilities, such as analytical thinking, learning, or complex problem solving (White, 1997, p. 156ff). One can easily detect the Kantian heritage behind this list. Given this summary, White continues by criticizing the nature of these features. The person who is constructed here is an independent, autonomous self, revolving, so to speak, around itself and its own logos. This conceptualization can be called logocentric and egocentric. In fact, for almost all of these person-conferring features to be present an individual need not be surrounded by or in relation with any other persons, with the exception of feature 7. The orthodox concept of person, so White observes, constructs a "Separate Self" precisely because it concentrates so much on self-awareness as a solitary process. This might be problematic for both humans and other animals, who could be better characterized as "Connected Selves," or "Social Selves" (White, 1997, p. 175ff).

Locke's definition is the starting point for Rowlands. It is as solipsistic and rationalistic as Kant's conception: a person is "a thinking intelligent being, that [...] can consider itself the same thinking thing" (Locke, 1690, p. 280), or, in Rowlands's (2016) words, persons can "make themselves - whether their bodies or their mental lives - into objects of their (higherorder) intentional acts" (p. 4). Thus, in the reflective model of self-awareness, the subject of the act of thinking is also the object of the act, and the mode of presentation of this object is also the same thinking thing. From a structural perspective (not a moral one), this seems pretty egocentric and at the same time pretty logocentric - and, in White's sense, solipsistic.

Can we understand self-awareness or the selves we talk about in another way? They could, for example, be constituted by the reflection of themselves and their own actions in the reactions of others. Understood this way, it might be constitutive of a person's selfawareness that she is considered as someone by others, not just that she considers herself as a thinking thing. Only an understanding of self-awareness focused on the connection between thinking and (social) action, rather than thinking alone, could capture this. The same holds for a concept of personhood that understood persons as Social Selves.

Having summarized Rowlands's conception of personhood as one concerned with lived bodies, with the connection between conscious experience, actions and goals of individuals, and having added White's way of understanding animal persons as Social Selves, 
we can ask whether Rowlands's ideas contain anything revolutionary. I argue that Rowlands provides a definition that releases the thinking thing from its thinking box and puts it back into its body and into real social life. He gets rid of some of the Lockean baggage (which, I have suggested, is egocentric and logocentric) and moves into a direction that not only allows us to describe self-awareness in animals but also invites a new understanding of the animal self.

Rowlands provides us with a tool to interpret animal behaviour that can shed some light on exactly those abilities - mainly social abilities - that have been neglected in orthodox characterisations of personhood. This goes hand in hand with animal cognition research turning increasingly toward socio-cognitive abilities in animals such as care behaviour, consolation (e.g., Clay \& de Waal, 2013), cooperation (e.g., Cheney, 2011), empathy (e.g., Bartal et al., 2011), helping behaviour or altruism (e.g., Warneken \& Tomasello, 2006; Warneken \& Tomasello, 2009). All of these behavioural patterns are constitutive of personhood, not just because some of them are cornerstones of moral agency in orthodox definitions, but already because the animal performing them is a pre-reflectively self-aware being.

\section{References}

Bartal, I. B.-A, Decety, J., \& Mason, P. (2011). Empathy and pro-social behavior in rats. Science 334 (6061): 1427-1430.

Cheney, D. L. (2011). Extent and limits of cooperation in animals. PNAS 108 (Suppl. 2): 10902-10909.

Clay, Z., \& de Waal, F. B. M. (2013). Bonobos respond to distress in others: Consolation across the age spectrum. PLOS ONE 8 (1): e55206. doi:10.1371/journal.pone.0055206.

Dennett, D. C. (1988). Brainstorms: philosophical essays on mind and psychology. Cambridge, MA: MIT Press.

Fletcher, J. (1979). Humanhood: Essays in biomedical ethics. Buffalo: Prometheus Books. Locke, J. (1690). An essay concerning human understanding. London: J. M. Dent and Sons, 1961.

Rowlands, M. (2016). Are animals persons? Animal Sentience 2016.101.

Warneken, F., \& Tomasello, M. (2006). Altruistic helping in human infants and young chimpanzees. Science 311 (5765): 1301-1303.

Warneken, F., \& Tomasello, M. (2009). Varieties of altruism in children and chimpanzees. Trends in Cognitive Sciences 13 (9): 397-402.

White, T. (2007). In defense of dolphins: the new moral frontier. Malden (MA); Oxford; Victoria: Blackwell Publishing. 